\title{
The Share of Pollution from Land Sources in PM Levels in the Region of Danish Straits, North and Baltic Seas
}

\author{
Mariusz ROGULSKI ${ }^{1 *}$, Artur BADYDA ${ }^{2}$, Szymon FIRLĄG ${ }^{3}$ \\ ${ }^{1,2}$ Warsaw University of Technology, Faculty of Building Services, Hydro and Environmental Engineering, \\ Nowowiejska 20, 00-653 Warsaw, Poland \\ ${ }^{3}$ Warsaw University of Technology, Faculty of Civil Engineering, Aleja Armii Ludowej 16, 00-637 Warsaw, \\ Poland
}

\begin{abstract}
The aim of the study was to determine air pollution over the sea surface (North Sea and Baltic Sea) comparing to concentration in the closest land areas to examine the impact of ships on the level of PM concentration. The analysis is based on the measurements made during the two weeks cruise of the tall ship Fryderyk Chopin from Edinburg to Kolobrzeg. The highest pollution levels were observed in locations distant from the coast, especially over Baltic Sea, with increasing concentrations when other ships approaching. The article attempts to assess the possibility of migration of pollutants to these areas from land-based sources, and thus indicate the degree of their participation in the level of pollution present at sea.
\end{abstract}

Keywords - Air pollution; Baltic Sea; marine traffic; North Sea; ships emissions

\section{INTRODUCTION}

Air pollution is currently a very essential and important problem concerning environment. To the pollutants in the air belong gases, liquids and solids, other than its natural components, or substances present in amounts significantly increased compared to the natural composition of the air. The most typical air pollutants are: carbon dioxide $\left(\mathrm{CO}_{2}\right)$, nitrogen oxides $\left(\mathrm{NO}_{\mathrm{x}}\right)$, ozone $\left(\mathrm{O}_{3}\right)$, sulfur oxides $\left(\mathrm{SO}_{\mathrm{x}}\right)$, organic compounds and particulate matter.

In many places of the world one of the most common air pollution is particulate matter (PM) [1], [2]. Its source can be of natural origin or anthropogenic. The main sources of anthropogenic PM emissions are the combustion of fuels by vehicles, industry, among others energy as well as heating of buildings with solid fuel furnaces, which is related to the lack of connection of households to heating networks [3], [4].

PM owes its different properties due to various emission sources. Particulate matter with a specific fraction in different places around the world differs in chemical composition, and thus influences variously on the human body. Regardless of the location, PM can be a serious pathogen, causing exacerbating asthma symptoms, respiratory diseases (e.g. pneumococcal disease), or cardiovascular disease [5], [6]. Furthermore, it provokes numerous physical and chemical processes in the atmosphere. Particulate matter after penetrating into the atmosphere, create an atmospheric aerosol. The essential components of PM are carbon matter, mineral matter, inorganic aerosol and water. There are also many other components

* Corresponding author.

E-mail address: Mariusz.Rogulski@pw.edu.pl 
that settle on its surface as a result of the combustion processes like: polycyclic aromatic hydrocarbons (e.g. benzo(a)pyrene) or trace metals (e.g. lead, cadmium or arsenic).

The time it stays in the atmosphere depends on its fraction $\left(\mathrm{PM}_{10}, \mathrm{PM}_{2,5}\right.$, etc.). Due to its specificity, air pollutants can move quickly, covering large areas. $\mathrm{PM}_{10}$ can persist in the air for 10-30 days and can be transported over distances up to $1000 \mathrm{~km}$. There are many factors that affect the range of air pollution transfer and the speed of transfer, which leads to very dynamic changes in air quality. Factors such as wind speed and terrain significantly affect the speed of dust spread.

The most attention concerning identification of emission sources and methods of measuring the concentration of various fractions of PM is devoted to land areas. However, air pollution over the seas is described to a much lesser extent in the scientific researches. The main reason for this is the technical difficulty in making such measurements. In [7], ship exhaust emissions in the Sea of Marmara and the Turkish Straits were calculated taking into account the main engine, fuel type and operation, navigation times and vessel speed. Researches have shown that marine emissions in the area accounted for $25 \%$ of PM emissions and were higher than emissions from airplanes and railways. The authors [8], [9] described the measurement campaigns organized in 2009, 2010 and 2011 in the western Mediterranean in order to analyse the sources of pollution as well as the emissions of substances contained in $\mathrm{PM}_{10}$. It has been presented a dependence between the presence of sulphates, vanadium and nickel in the air and the number of passing ships. A precise marine emission inventory for ocean-going vessels in Hong Kong was developed in [10]. The total ship emissions from 37150 voyages in 2007 were found to be 1035 tonnes, which is $16 \%$ of the total $\mathrm{PM}_{10}$ emissions. In the analysis [11] was developed a comprehensive inventory of ship emissions on a national scale for China, with a resolution of $0.005^{\circ} \times 0.005^{\circ}$, using a methodology based on information from the Automatic Identification System (AIS) from the full 2014 year. In [12], research carried out during cruises presented that there are alkanes polycyclic aromatic hydrocarbons (PAHs) and organic compounds in the particulate matter in the air. Significant differences were found in the concentration and percentage composition between port areas, full seas and ship routes. Research has shown that the main source of PAHs in ports and at sea were substances derived from fuels.

The source of PMs over the seas and oceans is not only the burning of fuels by ships but also transport from land areas. Long-distance pollution transport is the subject of many scientific papers. The authors [13] examined transport routes and potential sources of $\mathrm{PM}_{10}$ concentration based on data from 2003-2009 in the Beijing region. They identified four transport routes for abundant amounts of $\mathrm{PM}_{10}$. In turn, in [14], [15] was carried out an analysis of very long-lasting presence of high $\mathrm{PM}_{10}$ concentrations in Seoul caused by the transport of pollutions from China. Upstream air pollutants from the source region in China were studied in the context of horizontal and vertical air flows. A similar analysis was presented in [16], where a specific, regional transport model was created to simulate the concentration of $\mathrm{PM}_{10}$ and to study the influence of long-distance air pollution transport to Delhi. In [17], statistical methods were used to characterize the main atmospheric circulation patterns that transport air masses and to identify geographically the main potential source areas of each $\mathrm{PM}_{10}$ category. In turn, [18] analysed the influence of pollution from ships on air quality in coastal areas of Europe. The authors concluded that emissions from maritime transport not only affect the value and composition of particulate and gaseous pollutants, but may also exacerbate new particle formation processes in urban areas.

The aim of this article is to indicate the impact of particulate matter emissions from terrestrial sources on PM levels in the region of Danish straits, North and Baltic Seas. The second goal was to compare the amount of pollutants emitted from land-based sources 
with those emitted by ships. Data for analysis were collected during almost a half-month cruise from the port of Edinburgh (GB) to the port of Kołobrzeg (PL) in the second half of September 2017.

\section{Methods ANd Methodology}

During a cruise on the seas, it would be difficult to use reference measurement instruments and obtain measurements with a resolution of, for example, one minute. Therefore, for this purpose, a portable measuring device was used to measure the concentration of $\mathrm{PM}_{10}, \mathrm{PM}_{2.5}$ and $\mathrm{PM}_{1}$, temperature and relative humidity. The device using optical sensors was used many times during other measurement campaigns, and the algorithms used to improve the accuracy of measurements were described, among others, in [19]-[23]. The resolution of the measurements was one minute. During each individual measurement, the concentration of $\mathrm{PM}_{10}, \mathrm{PM}_{2.5}$ and $\mathrm{PM}_{1}$, air temperature, relative air humidity were measured, and the date, hour, minute and second of the measurement as well as the current location using GPS were recorded and saved on the SD card inside the measurement device.

The results of the measurement campaign for measuring the concentration of particulate matter presented in this article were carried out during the cruise on the sailing ship STS Fryderyk Chopin as part of the 'Politechnika na Fali' seminar organized by the Warsaw University of Technology (Poland) and addressed to its students. The main theme of the 2017 edition was 'Tools and challenges for modern engineers'. Carrying out air quality measurements at sea, for technical reasons, is not as easy as on the mainland, so it was decided to take advantage of the possibility of placing the measuring device on the mentioned ship. On the one hand, a one-off cruise cannot lead to unambiguous conclusions and generalizations, but on the other hand, even a single voyage may give some hints as to the need to conduct measurements in such places.

The cruise took place from September 17 to September 30, 2017. The most important locations and the dates of entry into ports and departure from ports during the cruise are presented in Table 1.

TABle 1. The Most Important Locations During the CRUiSe

\begin{tabular}{lll}
\hline Location & From & To \\
\hline Edinburgh (GB) & September 17, 4 pm & September 18, 2 pm \\
North Sea & September 18, 2 pm & September 21 \\
Danish Straits & September 22 & September 24, 5:30 pm \\
Copenhagen (DK) & September 24, 5:30 pm & September 26, 8:15 am \\
Baltic Sea & September 26, 8:15 am & September 28, 8:00 am \\
Kołobrzeg (PL) & September 28, 8:00 am & September 29, 6 pm \\
Szczecin (PL) & September 30 & \\
\hline
\end{tabular}

In order to minimize the influence of the ship's own emissions on the measurements, the measuring device was placed on the bow of the ship and the mast base at a height of about $1.7 \mathrm{~m}$ above the deck. Behind the device there were all the ship's own factors that could influence the measurements, such as ventilators from the engine room or the kitchen. The whole journey took place against the wind or in a side wind, which meant that the device examined the air flowing directly from the sea. Most of the voyage was under sails and without the use of a marine engine. The exhaust fumes from the engine and generator set out through a 32-meter-high chimney located in the midship mast. 


\section{Results}

The values of $\mathrm{PM}_{10}$ concentration measured during the cruise are shown in Fig. 1 and Fig. 2. A detailed analysis of the results obtained and a more detailed description of the cruise can be also found in [24].

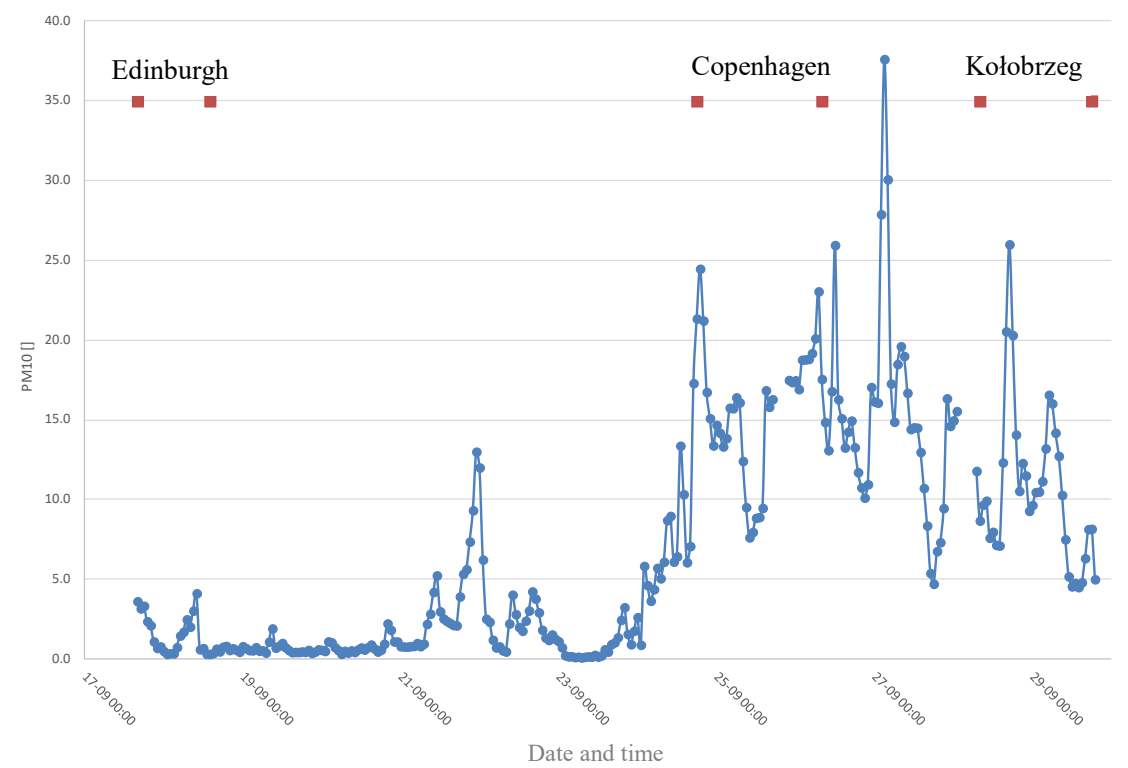

Fig. 1. Average hourly $\mathrm{PM}_{10}$ concentration $\left(\mu \mathrm{g} / \mathrm{m}^{3}\right)$ throughout the cruise from Edinburgh to Kołobrzeg.

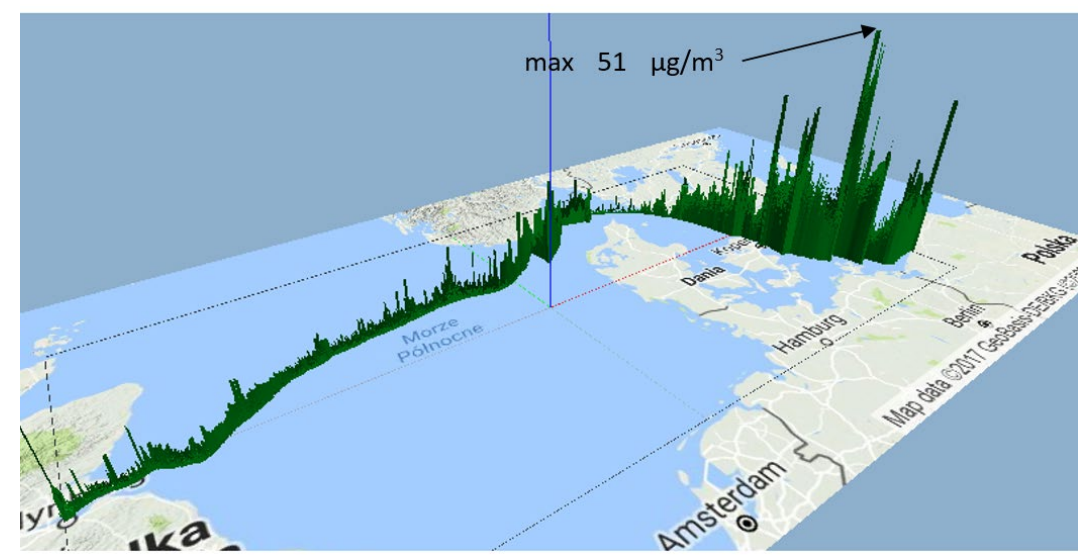

Fig. 2. Temporary $\mathrm{PM}_{10}$ concentrations $\left(\mu \mathrm{g} / \mathrm{m}^{3}\right)$ applied on the map with the cruise path (map created using [25]).

In the case of the cruise through the North Sea, it can be said that the impact of land sources on PM concentrations over the sea on most routes was practically negligible, as measured $\mathrm{PM}_{10}$ concentrations usually did not exceed $10 \mu \mathrm{g} / \mathrm{m}^{3}$, and most often fluctuated around $5 \mu \mathrm{g} / \mathrm{m}^{3}$. The only exception was the period on $21^{\text {st }}$ September from 23:00 to 24:00, when there was a certain increase in pollution - analysis of the shipping routes using the marine 
traffic service indicated that the sailing ship was close to the main route frequented by many other vessels (e.g. ships sailing from or to the Danish Straits) - Fig. 3.

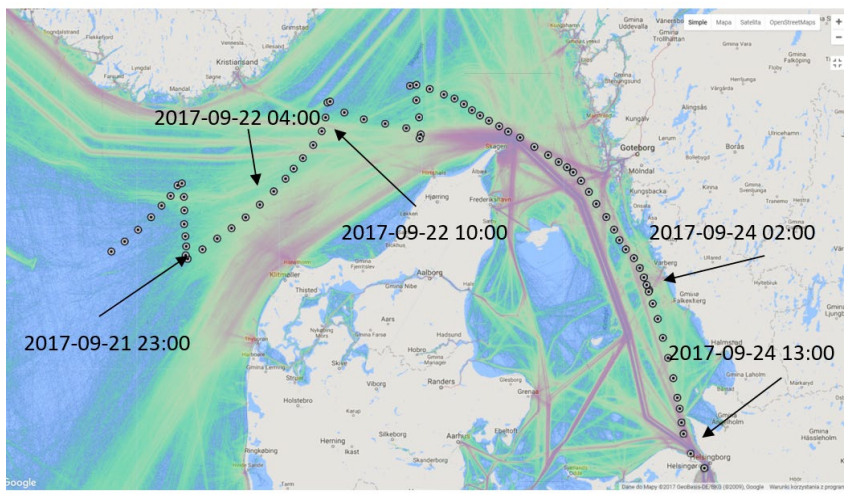

Fig. 3. Shipping traffic intensity and main shipping lanes with the path of tall ship STS Fryderyk Chopin cruise from 9:00 on 21 September until 14:00 on 24 September (map created using [25]).

Another noticeable increase in $\mathrm{PM}_{10}$ concentration took place scarcely a few kilometres from the centre of Copenhagen (at 17:00 on September 24). After the ship's arrival at the port, the cycle of concentration changes took on an evident 'land-based' character - concentration values increased to their maximum in the evening (hourly PM $_{10}$ averages: $25 \mu \mathrm{g} / \mathrm{m}^{3}$ ), and minimum in the morning (hourly $\mathrm{PM}_{10}$ averages: $7.5 \mu \mathrm{g} / \mathrm{m}^{3}$ ). At east wind, the measured values were quite consistent with the results from the reference measuring stations in Copenhagen and Malmö Rådhuset.

After leaving the port of Copenhagen on September 26, $\mathrm{PM}_{10}$ concentration remained at around $15-17 \mu \mathrm{g} / \mathrm{m}^{3}$. These values are quite similar to those measured at the Malmö Rådhuset referential station (approx. 22-24 $\mu \mathrm{g} / \mathrm{m}^{3}$ ). The obtained values, in the absence of passing vessels, can be treated as a 'background', i.e. the level of concentration from land-based sources. The first local, quite large maximum was observed at 11:45 $\left(33 \mu \mathrm{g} / \mathrm{m}^{3} \mathrm{PM}_{10}\right.$, at this time at the Malmö Rådhuset referential station the $\mathrm{PM}_{10}$ concentration was about $20 \mu \mathrm{g} / \mathrm{m}^{3}$ ).

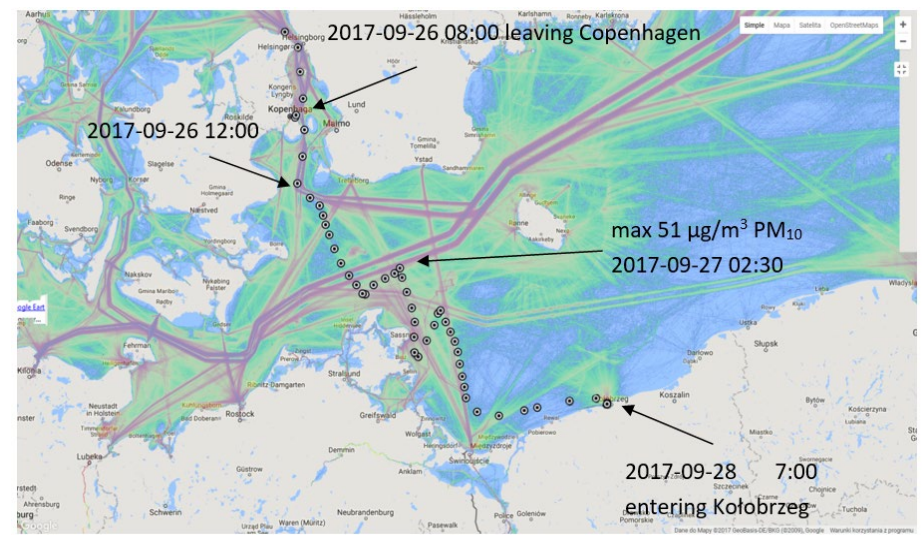

Fig. 4. Shipping traffic intensity and main shipping lanes with the path of tall ship STS Fryderyk Chopin cruise from 8:00 on $26^{\text {th }}$ September to 7:00 on $28^{\text {th }}$ September (map created using [25]). 


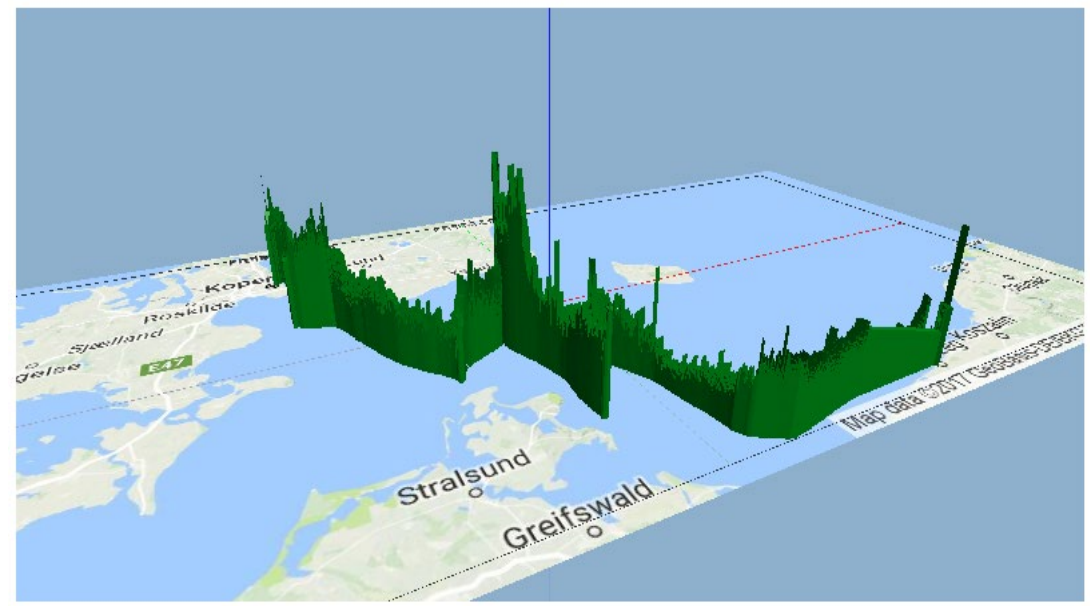

Fig. 5. Temporary $\mathrm{PM}_{10}$ concentrations $\left(\mu \mathrm{g} / \mathrm{m}^{3}\right)$ from 8:00 on $26^{\text {th }}$ September until 7:00 on $28^{\text {th }}$ September applied on the map with the cruise path (map created using [25]).

The probable reason for the increase in concentration was the proximity of the LübeckKoge shipping route. High values were maintained for over an hour. Over the next several hours, despite moderate wind (approx. 6-8 m/s), concentrations remained constant at 8 $15 \mu \mathrm{g} / \mathrm{m}^{3}$, not showing typical variability characteristic for terrestrial areas. This was much more than in the North Sea or the Skagerrak.

On September 27 at 2:30 the maximum $\mathrm{PM}_{10}$ concentrations during the entire cruise was measured $-51 \mu \mathrm{g} / \mathrm{m}^{3}$ (Fig. 4, Fig. 5). By analysing the trajectory of particle movement using meteorological data and the HYSPLIT Trajectory Model service (Fig. 6), it can be seen that the particles in this area came from the area between Koszalin and Słupsk (Poland). Particles in the area where the highest concentration occurred, the land area left at approx. 18 the previous day. The average 1-hour $\mathrm{PM}_{10}$ concentration at the reference station in Koszalin was then about $37 \mu \mathrm{g} / \mathrm{m}^{3}$. However, it should be remembered that the station measures pollution in the city, and the distance the particles travelled to the analysed point at sea was about $200 \mathrm{~km}$.

The high level of pollution remained for about two hours. The local nature of the growth suggests that the main source of pollution in this region was emissions from passing vessels. Analysing data from the marine traffic website, it can be seen that it is in this area that the trail leads from the depths of the Baltic Sea towards ports in northern Germany. Trying to estimate the impact of land-based sources of pollution here, we need to look at the levels of pollution before this maximum occurs. Before 2:00 am on September 27, they were around $20 \mu \mathrm{g} / \mathrm{m}^{3}$. In addition to PM from land sources, undoubtedly airborne pollution from other distant ships could also have some share. However, because the wind speed was quite significant, their share in the total level of pollution should not be significant (due to their dispersion). At the same time, when analysing the backward trajectories of the particles it can be indicated that they came to a large extent from the Polish coast. Considering the $\mathrm{PM}_{10}$ concentration values measured at the reference station in Koszalin or Słupsk, the measured values were quite high then - in the evening of September 26, 1-hour averages even exceeded the level of $50 \mu \mathrm{g} / \mathrm{m}^{3}$ in Koszalin and $40 \mu \mathrm{g} / \mathrm{m}^{3}$ in Słupsk. With moderate eastern and southeastern winds, undoubtedly some of these pollutants could reach the areas through which the voyage of the vessel on which the measuring device was mounted was carried out. 


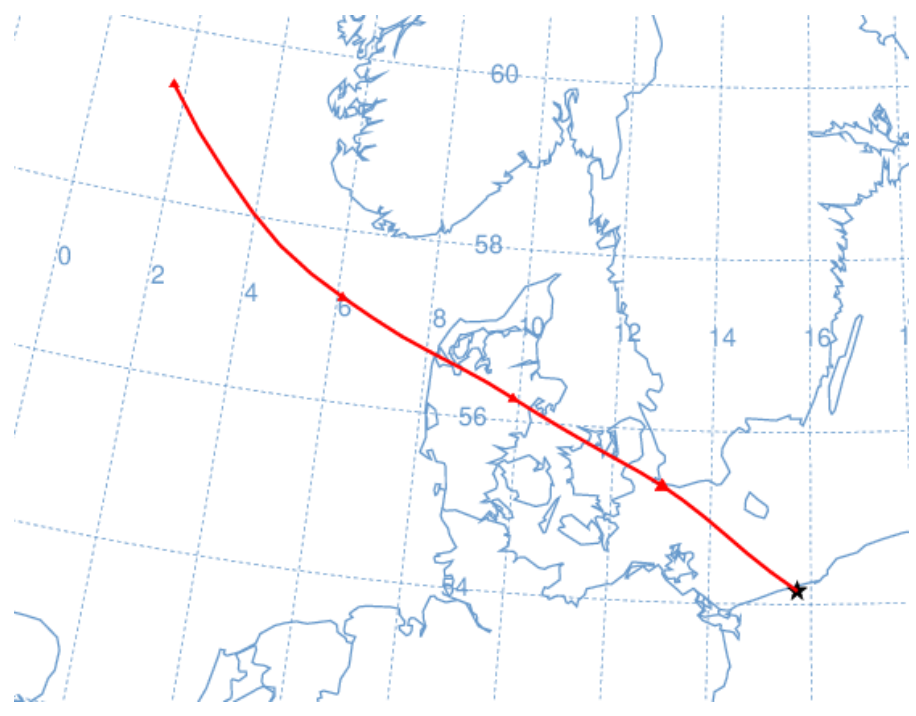

Fig. 6. Particle backward trajectory as the tall ship passes north of the island of Rügen (map created using [26]).

During the further cruise, the concentration dropped almost by half after passing another $5 \mathrm{~km}$, approx. $20 \mathrm{~km}$ from the German island - Rügen. Similar $\mathrm{PM}_{10}$ concentration persisted until the afternoon of September 27. As the distance from Rügen to the south-east, the level of $\mathrm{PM}_{10}$ decreased even more to $5-10 \mu \mathrm{g} / \mathrm{m}^{3}$. It increased again to $10-15 \mu \mathrm{g} / \mathrm{m}^{3}$ in the late evening hours of the same day, when the ship was about $30 \mathrm{~km}$ from the Polish coast. These values of $\mathrm{PM}_{10}$ concentration continued until the morning of September 28, when the ship arrived at the port in Kołobrzeg (at that time in Koszalin, $40 \mathrm{~km}$ away, the reference station recorded a $\mathrm{PM}_{10}$ concentration of about $25 \mu \mathrm{g} / \mathrm{m}^{3}$ ). During the stay in the port of Kołobrzeg, daily changes in $\mathrm{PM}_{10}$ concentrations were characteristic to the land areas (maximum concentrations were measured around 16:00-17:00). The distribution and changes in $\mathrm{PM}_{10}$ concentrations were similar to those during the stay in the port of Copenhagen.

In order to determine the potential impact of land-based sources on the concentrations of $\mathrm{PM}_{10}$ over the sea, it is necessary to analyse the values measured in relation to the distance from the land (in the direction of the wind). This relationship is shown in Fig. 7. The distance to land was determined from the wind direction weather data (e.g., from the cruise log shared by the captain of the tall ship) and the HYSPLIT trajectory model.

The resulting diagram shows a certain relationship between distance from land and the value of $\mathrm{PM}_{10}$ concentrations. Throughout the entire trip across the North Sea, the air quality was very good, making the impact of land sources on concentration values imperceptible. In the case of the Danish Straits, the ship sailed much closer to the mainland. Quite strong wind, as well as relatively low concentrations recorded at Swedish referential environmental monitoring stations meant that also here the air quality over water was also very good. It can be said that also in this area the influence of land sources was practically negligible. 


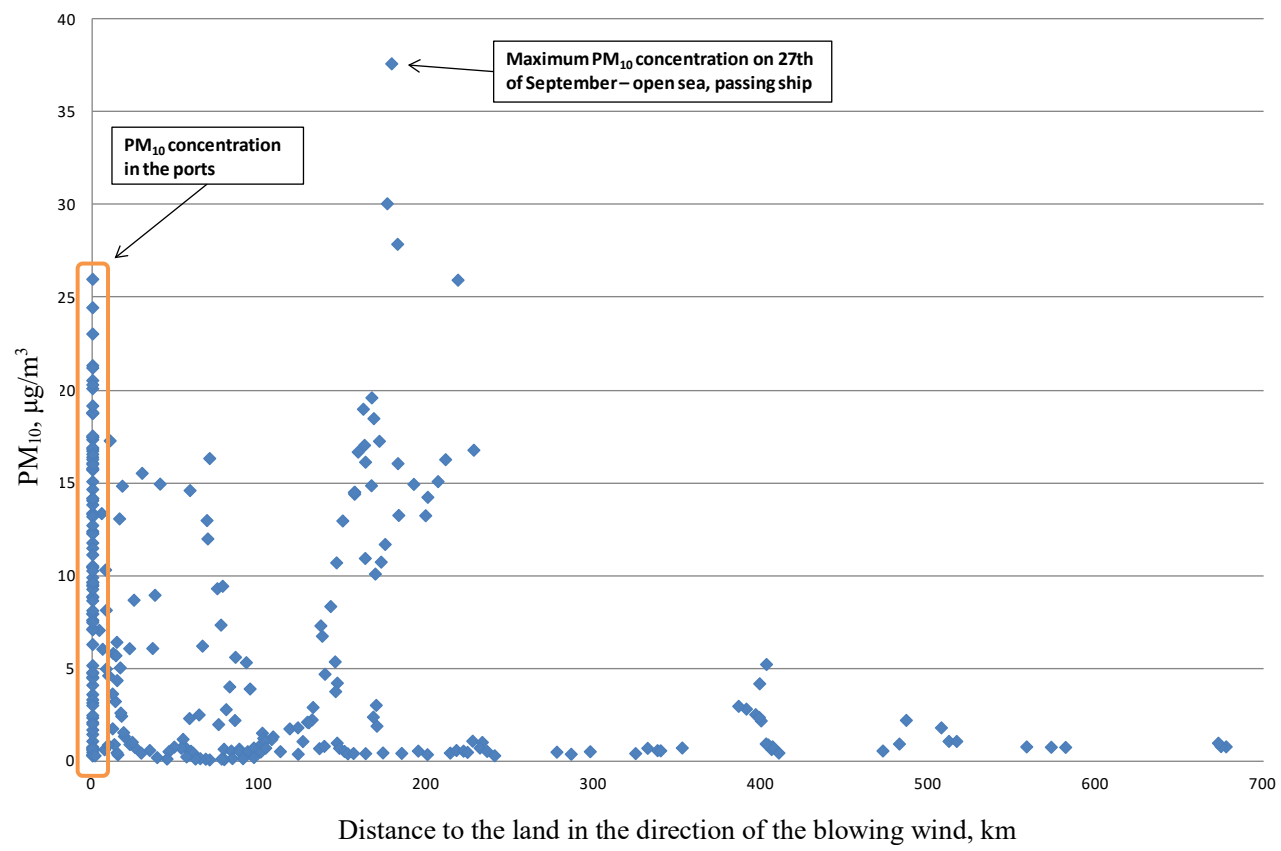

Fig. 7. Average hourly $\mathrm{PM}_{10}$ concentrations $\left(\mu \mathrm{g} / \mathrm{m}^{3}\right)$ in relation to the distance to the land $(\mathrm{km})$ considering the direction of wind.

A completely different situation occurred in the Baltic Sea. Here, for most of the cruise, typical $\mathrm{PM}_{10}$ concentrations fluctuated around $15-20 \mu \mathrm{g} / \mathrm{m}^{3}$. At the same time, the distance from the mainland was smaller than in the case of a North Sea cruise. The observed maximum (over $50 \mu \mathrm{g} / \mathrm{m}^{3}$ ) was undoubtedly caused by pollution emitted by passing ships. However, in the remaining area, land sources could have been involved in these much higher $\mathrm{PM}_{10}$ pollution than in the North Sea or in the Danish Straits. When comparing typical $\mathrm{PM}_{10}$ concentrations in the North Sea (approx. 5-7 $\mu \mathrm{g} / \mathrm{m}^{3}$ ) to typical $\mathrm{PM}_{10}$ concentrations in the Baltic (approx. 15-20 $\mu \mathrm{g} / \mathrm{m}^{3}$ ), it can be seen that the difference in $\mathrm{PM}_{10}$ concentrations was on average approx. 10-12 $\mu \mathrm{g} / \mathrm{m}^{3}$. Emissions from land-based sources were also higher in this case than in the areas surrounding the North Sea or the Danish Straits. As the analysis of the particle backward trajectory showed, with the wind blowing from the south-east, pollution on the Baltic could originate from the Polish coast. In the hours preceding the cruise of the ship in the Baltic Sea, the $\mathrm{PM}_{10}$ concentrations recorded at the measuring stations in Koszalin or Słupsk indicated respectively: over $50 \mu \mathrm{g} / \mathrm{m}^{3}$ and about $40 \mu \mathrm{g} / \mathrm{m}^{3}$. This is much more than in the case of coastal referential environmental monitoring stations in Sweden, which usually show $\mathrm{PM}_{10}$ values of approx. $20-25 \mu \mathrm{g} / \mathrm{m}^{3}$. The difference between these average overland values therefore suggests that this increase in average $\mathrm{PM}_{10}$ concentrations in the Baltic compared to $\mathrm{PM}_{10}$ in the North Sea was caused precisely by land-based sources.

\section{Conclusions}

One of the possibilities of determining the concentration of $\mathrm{PM}_{10}$ above the seas is to place an appropriate measuring device on the ship. In the analysed example, for this purpose the cruise of the tall ship STS Fryderyk Chopin was used. Despite the fact that a single cruise 
cannot be a reason to generalize the observations, on its basis it can be indicated that the air over the North Sea and the Danish Straits during the cruise was much cleaner. The impact of the emission sources from the mainland in this case was minimal - one of the reasons could be the low $\mathrm{PM}_{10}$ concentration observed by the Swedish reference environmental monitoring stations on the coast (where the wind was blowing from), the large distance from the mainland in the case of the North Sea, and strong winds.

In the case of measurements made during a cruise on a tall ship in the Baltic Sea, the average $\mathrm{PM}_{10}$ concentrations were about $10-12 \mu \mathrm{g} / \mathrm{m}^{3}$ higher than in the North Sea. With a similar intensity of ship traffic as, for example, in the Danish Straits, this may indicate that the increase in pollution on such a scale could have been influenced by emission sources located on the mainland. It was also important in this case that higher concentrations were also measured on the coast, which was the source of the particles measured during the cruise, and usually a much shorter distance from the land than in the North Sea.

On the other hand, it is difficult to make general statements from a single cruise, but even this single cruise has shown that ships are a very important source of pollutant emissions. This is probably especially important in areas where there is a lot of ship traffic and where the sea is not very large (compared to others in the world). For this reason, it seems that the attention that is paid in many countries to the reduction of pollutant emissions from land sources should also be attached to the reduction of emissions from ships. To sum up, on the one hand, there is a need to measure air quality in the seas and oceans, and on the other hand - changes are required to reduce pollutant emissions in maritime transport.

\section{ACKNOWLEDGEMENT}

We gratefully thank Captain Bartłomiej Skwara for the support.

\section{REFERENCES}

[1] Pope C. A., Bates D. V., Raizenne M. E. Health effects of particulate air pollution: Time for reassessment? Environmental Health Perspectives 1995:103:472-480. https://doi.org/10.1289/ehp.95103472

[2] Czechowski P. O., et al. Preliminary Attempt at the Identification and Financial Estimation of the Negative Health Effects of Urban and Industrial Air Pollution Based on the Agglomeration of Gdańsk. Sustainability 2020:12:42. https://doi.org/10.3390/su12010042

[3] Priedniece V., et al. Treatment of Particulate Matter Pollution: People's Attitude and Readiness to Act. Environmental and Climate Technologies 2020:24(2):231-246. https://doi.org/10.2478/rtuect-2020-0069

[4] Bajcinovci B. Environmental and Climate Dilemma: Coal for Heating or Clean Air for Breathing: A Case of Prishtina Environmental and Climate Technologies 2019:23(1):41-51. https://doi.org/10.2478/rtuect-2019-0003

[5] Yang X. L., et al. Associations of long-term exposure to ambient $\mathrm{PM}_{2.5}$ with mortality in Chinese adults: A pooled analysis of cohorts in the China-PAR project. Environment International 2020:138:105589. https://doi.org/10.1016/j.envint.2020.105589

[6] Tellez-Rojo M. M., et al. Children's acute respiratory symptoms associated with $\mathrm{PM}_{2.5}$ estimates in two sequential representative surveys from the Mexico City Metropolitan Area. Environmental Research 2020:180:108868. https://doi.org/10.1016/j.envres.2019.108868

[7] Deniz C., Kilic A., C1vkaroglu G. Estimation of shipping emissions in Candarli Gulf, Turkey. Environmental monitoring and assessment 2010:171:219-228. https://doi.org/10.1007/s10661-009-1273-2

[8] Bove M. C., et al. $\mathrm{PM}_{10}$ source apportionment applying PMF and chemical tracer analysis to shipborne measurements in the western Mediterranean. Atmospheric Environment 2016:125:140-151. https://doi.org/10.1016/j.atmosenv.2015.11.009

[9] Schembari C., et al. Source apportionment of $\mathrm{PM}_{10}$ in the Western Mediterranean based on observations from a cruise ship. Atmospheric Environment 2014:98:510-518. https://doi.org/10.1016/j.atmosenv.2014.09.015

[10] Yau P. S., et al. Estimation of exhaust emission from ocean-going vessels in Hong Kong. Science of The Total Environment 2012:431:299-306. https://doi.org/10.1016/j.scitotenv.2012.03.092 
[11] Chen D., et al. High-spatiotemporal-resolution ship emission inventory of China based on AIS data in 2014. Science of The Total Environment 2017:609:776-787. https://doi.org/ 10.1016/j.scitotenv.2017.07.051

[12] Romagnoli P., et al. Particulate PAHs and $n$-alkanes in the air over Southern and Eastern Mediterranean Sea. Chemosphere 2016:159:516-525. https://doi.org/10.1016/j.chemosphere.2016.06.024

[13] Zhu L., et al. Transport pathways and potential sources of $\mathrm{PM}_{10}$ in Beijing. Atmospheric Environment 2011:45(3):594 604. https://doi.org/10.1016/j.atmosenv.2010.10.040

[14] Lee S., et al. Impacts of atmospheric vertical structures on transboundary aerosol transport from China to South Korea. Scientific Reports 2019:9:13040. https://doi.org/10.1038/s41598-019-49691-z

[15] Oh H.-R., et al. Long-range transport of air pollutants originating in China: A possible major cause of multi-day high$\mathrm{PM}_{10}$ episodes during cold season in Seoul, Korea. Atmospheric Environment 2015:109:23-30. https://doi.org/10.1016/j.atmosenv.2015.03.005

[16] Gupta M., Mohan M. Assessment of contribution to $\mathrm{PM}_{10}$ concentrations from long range transport of pollutants using WRF/Chem over a subtropical urban airshed. Atmospheric Pollution Research 2013:4(4):405-410. https://doi.org/10.5094/APR.2013.046

[17] Salvador P., et al. Composition and origin of $\mathrm{PM}_{10}$ in Cape Verde: Characterization of long-range transport episodes. Atmospheric Environment 2016:127:326-339. https://doi.org/10.1016/j.atmosenv.2015.12.057

[18] Viana M., et al. Impact of maritime transport emissions on coastal air quality in Europe. Atmospheric Environment 2014:90:96-105. https://doi.org/10.1016/j.atmosenv.2014.03.046

[19] Rogulski M., Badyda A. Investigation of Low-Cost and Optical Particulate Matter Sensors for Ambient Monitoring. Atmosphere 2020:11(10):1040. https://doi.org/10.3390/atmos11101040

[20] Owczarek T., Rogulski M., Czechowski O. Verification of equivalence with reference method for measurements of $\mathrm{PM}_{10}$ concentrations using low-cost devices. Scientific Journals of The Maritime University of Szczecin 2019:60(132):84-89. https://doi.org/10.17402/375

[21] Rogulski M. Indoor $\mathrm{PM}_{10}$ concentration measurements using low-cost monitors in selected locations in Warsaw. Energy Procedia 2018:147:137-144. https://doi.org/10.1016/j.egypro.2018.07.043

[22] Owczarek T., Rogulski M., Badyda A. Preliminary comparative assessment and elements of equivalence of air pollution measurement results of portable monitoring stations with using stochastic models. E3S Web of Conferences 2018:28:01028. https://doi.org/10.1051/e3sconf/20182801028

[23] Czechowski O., et al. Preliminary comparative assessment of $\mathrm{PM}_{10}$ hourly measurement results from new monitoring stations type using stochastic and exploratory methodology and models. E3S Web of Conferences 2018:28:01010. https://doi.org/10.1051/e3sconf/20182801010

[24] Firląg Sz., Rogulski M., Badyda A. The Influence of Marine Traffic on Particulate Matter (PM) Levels in the Region of Danish Straits, North and Baltic Seas. Sustainability 2018:10(11):4231. https://doi.org/10.3390/su10114231

[25] GPS Visualizer [Online]. [Accessed 15.01.2021]. Available: https://www.gpsvisualizer.com/

[26] HYSPLIT Trajectory Model [Online]. [Accessed 15.01.2021]. Available: https://www.ready.noaa.gov/index.php 